\title{
Local patchiness of Gyrodactylus colemanensis and $G$. salmonis parasitizing salmonids in the South River watershed, Nova Scotia, Canada
}

\author{
Ping You ${ }^{1, *}$, John MacMillan ${ }^{2}$, David Cone ${ }^{3}$ \\ ${ }^{1}$ College of Life Science, Shaanxi Normal University, Xi'an 710062, PR China \\ ${ }^{2}$ Nova Scotia Department of Fisheries and Aquaculture, Pictou, Nova Scotia B0K 1H0, Canada \\ ${ }^{3}$ Department of Biology, Saint Mary's University, Halifax, Nova Scotia B3H 3C3, Canada
}

\begin{abstract}
Prevalence and intensity of Gyrodactylus colemanensis and G. salmonis (Monogenea) parasitizing juvenile/adult brook trout Salvelinus fontinalis, rainbow trout Oncorhynchus mykiss, brown trout Salmo trutta, and Atlantic salmon Salmo salar at 3 localities over an $8 \mathrm{~km}$ stretch in the South River, Nova Scotia, Canada, were calculated 4 times over a 9 mo period (October 2009, December 2009, March 2010, June 2010). G. colemanensis was on all 4 salmonids (endemic and non-endemic), while G. salmonis parasitized mostly $S$. fontinalis (endemic) and occasionally $S$. trutta (non-endemic). At an upstream locality, beyond a waterfall barrier, in a small tributary of the main river, G. colemanensis was more common than G. salmonis. In the main river, $7 \mathrm{~km}$ downstream, prevalence of $G$. colemanensis on $S$. fontinalis was comparable, or higher, than that of G. salmonis, while intensity of G. salmonis was higher than that of G. colemanensis. Downstream a further $1 \mathrm{~km}$, in a tributary of the main river, both prevalence and intensity of G. salmonis on brook trout were higher than those of G. colemanensis. Stocks at a local trout hatchery had only G. colemanensis. The present study reports on a method by which exit water from such farms can be monitored for gyrodactylid parasites through a simple settling procedure. We estimated that up to 230000 dislodged, live G. colemanensis exit the hatchery daily in discharge water entering the river. It is suggested that such systems are ideal for studying the impact of such parasite export on the nature of local parasite populations.
\end{abstract}

KEY WORDS: Prevalence · Intensity · Gyrodactylus colemanensis · Gyrodactylus salmonis South River $\cdot$ Salmonids $\cdot$ Nova Scotia $\cdot$ Canada

\section{INTRODUCTION}

Species of Gyrodactylus Nordmann, 1832 are histozoic, viviparous ectoparasites (Monogenea) with a direct life cycle and great potential to cause a highly infectious disease in both captive and wild fish (Bakke et al. 2007). Salmonid fishes in North America are parasitized by at least 5 species in the genus. Two (G. colemanensis Mizelle \& Kritsky, 1967 and G. salmonis [Yin \& Sproston, 1948]) are known to have widespread geographical distributions on various salmonids in Canada and the USA (Cone et al. 1983). G. nerkae Cone, Beverley-Burton, Wiles, \& McDonald, 1983 is also considered a salmonid parasite (Cone et al. 1983), but is known only from Oncorhynchus nerka in southern British Columbia (Bailey \& Margolis 1987). G. avalonia Hanek \& Threlfall, 1969 and G. brevis Crane \& Mizelle, 1967, are occasionally found on salmonid fishes, but the preferred hosts are gasterosteids and a cyprinid, respectively. Research to date on the gyrodactylids of salmonids in North America has involved mostly 
captive fish stocks, with a few studies describing infections on wild hosts (Hathaway \& Herlevich 1973, Bailey \& Margolis 1987, Frimeth 1987a,b). This stands in sharp contrast to the numerous studies available on the gyrodactylids of wild salmonids in Eurasia (Bakke et al. 2007, Anttlila et al. 2008, von Gersdorff Jørgensen et al. 2008). In the present study, we report on the prevalence and intensity of $G$. colemanensis and $G$. salmonis parasitizing 4 salmonid species in the South River watershed, Nova Scotia, as well as on infected stocks at a fish hatchery within the watershed.

\section{MATERIALS AND METHODS}

The South River Drainage basin is located in northeastern Nova Scotia and drains northward approximately $31.7 \mathrm{~km}$ (MacMillan \& Madden 2007) to the marine waters of the Northumberland Strait (Figs. 1 $\& 2$ ). The valley is considered rural, and includes patches of Acadian mixed forest and livestock farms and fields. The main branch of the river is 7 to $10 \mathrm{~m}$ wide, with an average depth of $0.3 \mathrm{~m}$, and drains numerous small tributaries. It has a $\mathrm{pH}$ ranging from 7.0 to 7.4 , a mix of riffle to flat run, and a substrate of rock, cobble, and boulders. Water temperature at the time of sampling ranged from 2 to $17^{\circ} \mathrm{C}$. Aquatic vegetation is sparse in the river, and limited mostly to isolated shallow patches. The river and its tributaries are bordered by a strip of mixed forest and overhanging alders. Mean monthly flow rate at St. Andrews ranged from $1.65 \mathrm{~m}^{3} \mathrm{~s}^{-1}$ in July to $7.65 \mathrm{~m}^{3}$ $\mathrm{s}^{-1}$ in December over a $61 \mathrm{yr}$ period of sampling be-

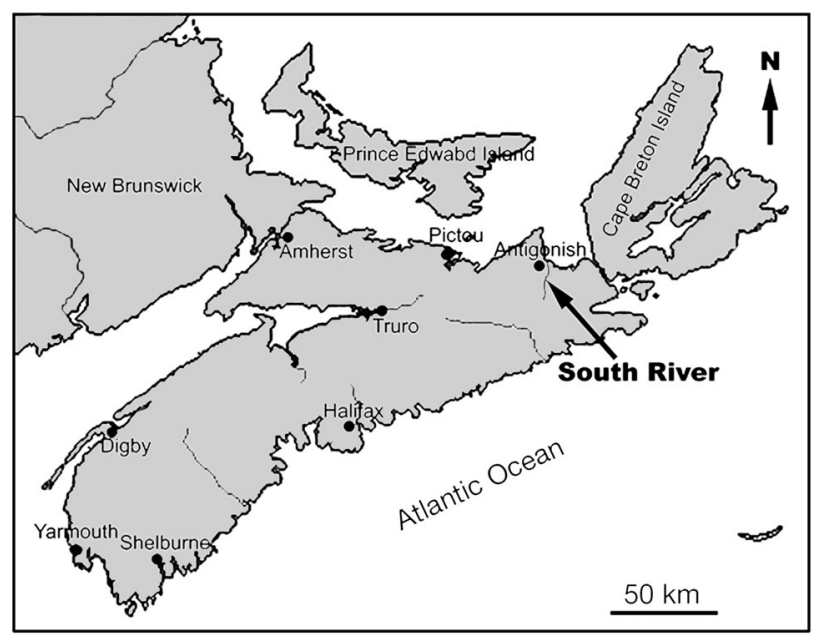

Fig. 1. Map showing the South River localities in northern Nova Scotia, Canada

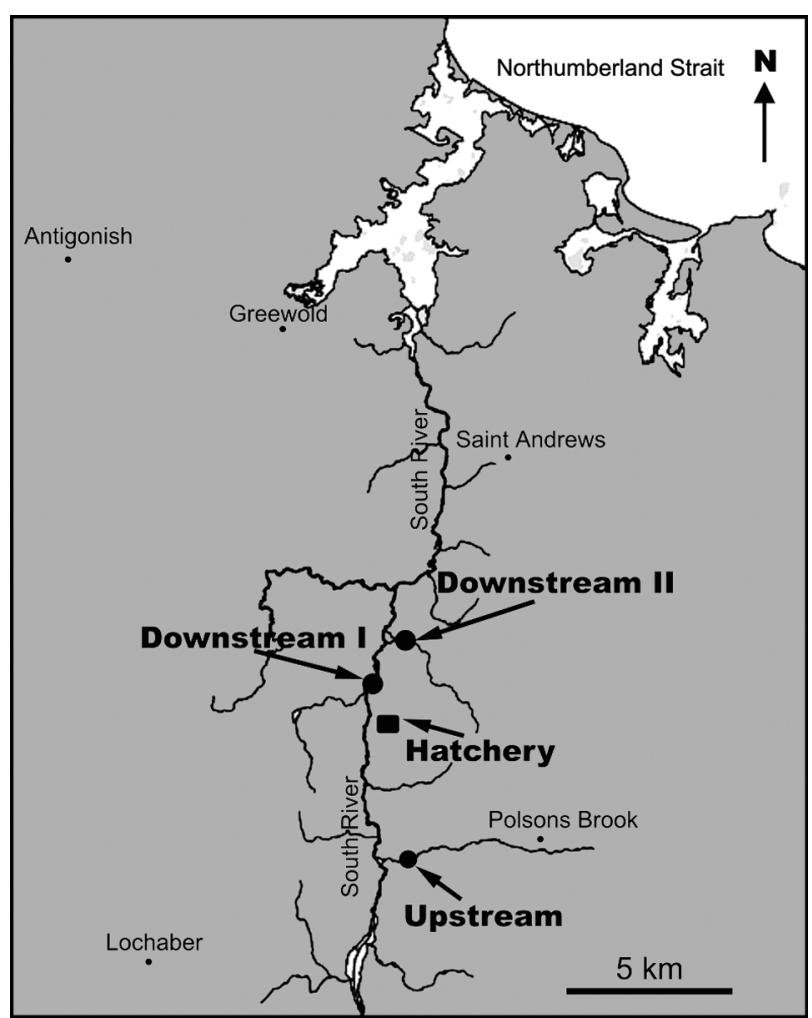

Fig. 2. Map showing the sample localities on the South River and its tributaries. Note how the sampling localities are embedded within a complex system of small tributaries

tween 1917 and 2008 (Environment Canada, www. wateroffice.ec.gc.ca/).

Four species of salmonids are in the South River: brook trout Salvelinus fontinalis (Mitchill, 1814); brown trout Salmo trutta Linnaeus, 1758; rainbow trout Oncorhynchus mykiss (Walbaum, 1792): and Atlantic salmon Salmo salar Linnaeus, 1758. Within the stretch of river sampled, $S$. fontinalis is the dominant species, followed by $S$. trutta and O. mykiss, and then $S$. salar. This relative abundance is reflected in the number of fish sampled (Table 1).

The 4 sampling localities were within an $8 \mathrm{~km}$ stretch of the river, located centrally within the drainage basin, and incorporated about $50 \mathrm{~m}$ each (Fig. 2). They included: Polson's Brook Tributary ('Upstream') $\left(45^{\circ} 27^{\prime} \mathrm{N}, 61^{\circ} 54^{\prime} \mathrm{W}\right)$ located upstream, $6 \mathrm{~km}$ from Fraser's Mills Fish Hatchery (5 to $12 \mathrm{~m}$ wide; 0.2 to $0.4 \mathrm{~m}$ deep; $\mathrm{pH} \mathrm{7.2;} \mathrm{conductivity} 4.8 \times$ $10^{-4} \mathrm{~S} \mathrm{~m}^{-1}$; total dissolved solids [TDS] $31.2 \mathrm{mg} \mathrm{l}^{-1}$; dissolved oxygen $9 \mathrm{mg} \mathrm{l}^{-1}$; substrate cobble to gravel with partial tree overhang); Fraser's Mills Fish Hatchery $\left(45^{\circ} 29^{\prime} \mathrm{N}, 61^{\circ} 56^{\prime} \mathrm{W}\right)$; Downstream I located $2 \mathrm{~km}$ downstream of Frasers Mills on the main branch $\left(45^{\circ} 30^{\prime} \mathrm{N}, 61^{\circ} 56^{\prime} \mathrm{W}\right)$ (8 to $11 \mathrm{~m}$ wide; 0.1 to 
Table 1. Summary of total length and sample sizes of Salvelinus fontinalis, Salmo trutta, Oncorhynchus mykiss, and Salmo salar collected during the course of the study. Dashes indicate that the species was not found at this site.

\begin{tabular}{|c|c|c|c|c|c|c|c|c|}
\hline \multirow[t]{2}{*}{ Site } & \multicolumn{2}{|c|}{ Salvelinus fontinalis } & \multicolumn{2}{|c|}{ Oncorhynchus mykiss } & \multicolumn{2}{|c|}{ Salmo trutta } & \multicolumn{2}{|c|}{ Salmo salar } \\
\hline & $\begin{array}{l}\text { Length } \\
\text { (cm) }\end{array}$ & $\begin{array}{l}\text { Sample } \\
\text { size }\end{array}$ & $\begin{array}{l}\text { Length } \\
(\mathrm{cm})\end{array}$ & $\begin{array}{l}\text { Sample } \\
\text { size }\end{array}$ & $\begin{array}{l}\text { Length } \\
\text { (cm) }\end{array}$ & $\begin{array}{l}\text { Sample } \\
\text { size }\end{array}$ & $\begin{array}{l}\text { Length } \\
\text { (cm) }\end{array}$ & $\begin{array}{c}\text { Sample } \\
\text { size }\end{array}$ \\
\hline Upstream & $\begin{array}{l}11.1 \pm 2.4 \\
(6.6-16.9)\end{array}$ & 86 & - & - & - & - & - & - \\
\hline Hatchery & $\begin{array}{c}17.5 \pm 3.3 \\
(12.0-25.5)\end{array}$ & 40 & $\begin{array}{c}25.9 \pm 3.4 \\
(19.5-32.5)\end{array}$ & 40 & $\begin{array}{l}11.2 \pm 0.8 \\
(9.5-12.5)\end{array}$ & 10 & - & - \\
\hline Downstream I & $\begin{array}{l}11.2 \pm 5.0 \\
(4.3-28.5)\end{array}$ & 57 & $\begin{array}{l}17.7 \pm 10.0 \\
(8.8-37.0)\end{array}$ & 8 & $\begin{array}{l}13.4 \pm 5.9 \\
(6.8-31.5)\end{array}$ & 16 & $\begin{array}{c}9.3 \pm 2.2 \\
(6.9-12.6)\end{array}$ & 8 \\
\hline Downstream II & $\begin{array}{l}13.7 \pm 4.2 \\
(6.2-25.0)\end{array}$ & 60 & - & - & $\begin{array}{l}16.2 \pm 4.6 \\
(7.9-23.0)\end{array}$ & 14 & - & - \\
\hline
\end{tabular}

$0.4 \mathrm{~m}$ deep; $\mathrm{pH} 7$; conductivity $7.2 \times 10^{-4} \mathrm{~S} \mathrm{~m}^{-1}$; TDS $46.4 \mathrm{mg} \mathrm{l}^{-1}$; dissolved oxygen $10.1 \mathrm{mg} \mathrm{l}^{-1}$; substrate rock to cobble with partial tree overhang); Downstream II, an unnamed tributary $\left(45^{\circ} 31^{\prime} \mathrm{N}, 61^{\circ} 56^{\prime} \mathrm{W}\right)$, located $3 \mathrm{~km}$ downstream of Fraser's Mills, where it crosses under Route 316 ( 2.5 to $7 \mathrm{~m}$ wide; 0.1 to $0.7 \mathrm{~m}$ deep; pH 7.4; conductivity $97.5 \times 10^{-4} \mathrm{~S} \mathrm{~m}^{-1}$; TDS 63 mg lis i dissolved oxygen $9.9 \mathrm{mg} \mathrm{l}^{-1}$; substrate cobble with partial tree overhang). All physical and chemical features of the collection localities mentioned above were from June 16, 2010. The specific localities were chosen because they could be sampled reliably in all seasons, the main body of the river being inaccessible in winter and at high flow rates. Fish sampled were of comparable total length, except for the relatively small juvenile salmon (Table 1).

Wild fish were electro-fished; hatchery fish were dip-netted. Fish were bagged immediately at capture and stored on ice until frozen, typically within a few hours. They were thawed, length measured, and then necropsied for ectoparasites. This involved examining body washings (obtained by adding about $50 \mathrm{ml}$ of distilled water to the bag followed by agitation), and excised fins and gills. It became apparent that the parasites detached from the body surfaces and fins when thawed, as almost all were found in the body washings, with few on the gills. All fish were examined within 1 wk of capture. Each individual Gyrodactylus specimen was mounted in a temporary wet mount and examined microscopically for identification. The specimens were in good condition, with no evidence of freezer damage or deterioration as all of the internal organs were clearly visible and intact. Representative samples were fixed in $10 \%$ formalin or preserved in $95 \%$ ethanol. Voucher specimens have been deposited in the United States Parasite Collection, Beltsville, Maryland (Accession Numbers USNPC104764 for
G. colemanensis and USNPC104765 for G. salmonis). Prevalence values were compared using a chisquared test; intensities were compared using the non-parametric Kruskal-Wallis test.

The Fraser's Mills facility raises approximately 500000 Savelinus fontinalis from eggs and 40000 fall fingerlings of Oncorhynchus mykiss. Fingerlings of Salmo salar raised at another farm are held temporarily until stocked. Details of the farm layout and operation have been described previously (Cone \& Cusack 1988). Export of parasites from the farm was assessed at each seasonal sampling by the following method. Seven $10 \mathrm{l}$ plastic buckets were filled with water leaving the hatchery and entering the river and left undisturbed for 15 min to allow parasites to sink. Fluid was then carefully decanted from the buckets leaving about $500 \mathrm{ml}$ of water per bucket, which, in turn, was poured into glass Petri dishes for examination with aid of a stereomicroscope. This process was repeated 3 more times for a total of 2801 of exit water at each sampling visit. The decanted washings required about $5 \mathrm{~h}$ of microscopy to process. We used incident lighting and care was taken not to have too much sample debris in the dish as it obscured parasites. Most of the parasites found were alive, and their movement stood out against a still background of debris.

\section{RESULTS}

A total of 243 Savelinus fontinalis, 48 Oncorhynchus mykiss, 40 Salmo trutta, 8 juvenile Salmo salar were examined. Prevalence and mean intensity of Gyrodactylus colemanensis and G. salmonis on these fishes are presented (Table 2). In the river, $G$. colemanensis occurred on all 4 salmonids, predominantly brook and rainbow trout (chi squared test: $\chi^{2}=$ 
Table 2. Prevalence (\%; in parentheses the ratio of infected to total number of fish sampled) and mean $( \pm$ SD) intensity (in parentheses maximum intensity) of Gyrodactylus salmonis and G. colemanensis in the 4 salmonid fish species from the 4 sampled sites (see Fig. 2) throughout the study period that spanned the fall of 2009 to winter, spring, and summer of 2010. Dashes indicate that the fish species was not found at this site

\begin{tabular}{|c|c|c|c|c|c|c|c|c|c|}
\hline \multirow[t]{2}{*}{ Site } & \multirow[t]{2}{*}{ Parasite } & \multicolumn{2}{|c|}{ Savelinus fontinalis } & \multicolumn{2}{|c|}{ Oncorhynchus mykiss } & \multicolumn{2}{|c|}{ Salmo trutta } & \multicolumn{2}{|c|}{ Salmo salar } \\
\hline & & Prevalence & $\begin{array}{c}\text { Mean } \\
\text { intensity }\end{array}$ & Prevalence & $\begin{array}{l}\text { Mean } \\
\text { intensity }\end{array}$ & Prevalence & $\begin{array}{c}\text { Mean } \\
\text { intensity }\end{array}$ & Prevalence & $\begin{array}{c}\text { Mean } \\
\text { intensity }\end{array}$ \\
\hline \multirow[t]{2}{*}{ Upstream } & G. salmonis & $\begin{array}{c}36.1 \\
(31 / 86)\end{array}$ & $\begin{array}{c}4.3 \pm 5.8 \\
(30)\end{array}$ & - & - & - & - & - & - \\
\hline & G. colemanensis & $\begin{array}{c}86.1 \\
(74 / 86)\end{array}$ & $\begin{array}{c}10.6 \pm 10.3 \\
(43)\end{array}$ & - & - & - & - & - & - \\
\hline \multirow[t]{2}{*}{ Hatchery } & G. salmonis & 0 & 0 & 0 & 0 & 0 & 0 & - & - \\
\hline & G. colemanensis & $\begin{array}{c}90 \\
(36 / 40)\end{array}$ & $\begin{array}{c}10.9 \pm 11.8 \\
(50)\end{array}$ & $\begin{array}{c}70 \\
(28 / 40)\end{array}$ & $\begin{array}{c}4.8 \pm 5.4 \\
(28)\end{array}$ & $\begin{array}{c}10 \\
(1 / 10)\end{array}$ & 1 & - & - \\
\hline \multirow[t]{2}{*}{ Downstream I } & G. salmonis & $\begin{array}{c}42.1 \\
(24 / 57)\end{array}$ & $\begin{array}{c}16.8 \pm 29.8 \\
(143)\end{array}$ & 0 & 0 & 0 & 0 & 0 & 0 \\
\hline & G. colemanensis & $\begin{array}{c}59.7 \\
(34 / 57)\end{array}$ & $\begin{array}{c}6.6 \pm 6.8 \\
(27)\end{array}$ & $\begin{array}{l}87.5 \\
(7 / 8)\end{array}$ & $\begin{array}{c}5.9 \pm 3.2 \\
(10)\end{array}$ & $\begin{array}{c}31.3 \\
(5 / 16)\end{array}$ & $\begin{array}{l}2.4 \pm 1.7 \\
(5)\end{array}$ & $\begin{array}{l}37.5 \\
(3 / 8)\end{array}$ & $\begin{array}{c}1.3 \pm 0.6 \\
\quad(2)\end{array}$ \\
\hline \multirow[t]{2}{*}{ Downstream II } & G. salmonis & $\begin{array}{c}81.7 \\
(49 / 60)\end{array}$ & $\begin{array}{c}25.3 \pm 32.4 \\
(146)\end{array}$ & - & - & $\begin{array}{c}14.3 \\
(2 / 14)\end{array}$ & $\begin{array}{c}2 \\
(2)\end{array}$ & - & - \\
\hline & G. colemanensis & $\begin{array}{c}28.3 \\
(17 / 60)\end{array}$ & $\begin{array}{c}2.0 \pm 1.5 \\
(6)\end{array}$ & - & - & $\begin{array}{c}14.3 \\
(2 / 14)\end{array}$ & $\begin{array}{l}1.5 \pm 0.7 \\
(2)\end{array}$ & - & - \\
\hline \multirow[t]{2}{*}{ Total } & G. salmonis & $\begin{array}{c}42.8 \\
(104 / 243)\end{array}$ & $\begin{array}{c}17.1 \pm 27.9 \\
(146)\end{array}$ & 0 & 0 & $\begin{array}{c}5 \\
(2 / 40)\end{array}$ & $\begin{array}{c}2 \\
(2)\end{array}$ & 0 & 0 \\
\hline & G. colemanensis & $\begin{array}{c}66.3 \\
(161 / 243)\end{array}$ & $\begin{array}{c}9.0 \pm 9.8 \\
(50)\end{array}$ & $\begin{array}{c}72.9 \\
(35 / 48)\end{array}$ & $\begin{array}{c}5.0 \pm 5.0 \\
(28)\end{array}$ & $\begin{array}{c}20 \\
(8 / 40)\end{array}$ & $\begin{array}{c}2.0 \pm 1.4 \\
(5)\end{array}$ & $\begin{array}{l}37.5 \\
(3 / 8)\end{array}$ & $\begin{array}{c}1.3 \pm 0.6 \\
(2)\end{array}$ \\
\hline
\end{tabular}

35.8, $\mathrm{p}<0.001$; Kruskal-Wallis test: $H=18.3, \mathrm{p}<$ 0.001 ) and to a lesser extent on brown trout and Atlantic salmon (Table 2). G. salmonis occurred almost exclusively on $S$. fontinalis, and rarely on $S$. trutta (Table 2).
Occurrence of the 2 parasites on brook trout is compared by site (Table 3 ). Prevalence (Gyrodactylus salmonis, $\chi^{2}=6.1$ to $20.4, \mathrm{p}<0.025$; G. colemanensis, $\chi^{2}=7.7$ to $\left.29.7, \mathrm{p}<0.025\right)$ and mean intensity $(G$. salmonis, $H=5.80$ to 13.72 , p $<0.05$; G. colemanen-

Table 3. Prevalence (\%; in parentheses the ratio of infected to total number of fish sampled) and mean ( \pm SD) intensity (in parentheses maximum intensity) of Gyrodactylus salmonis and G. colemanensis parasitizing Salvelinus fontinalis from the 4 sampled sites (see Fig. 2). We were unable to sample the Downstream II locality in winter due to ice and high water

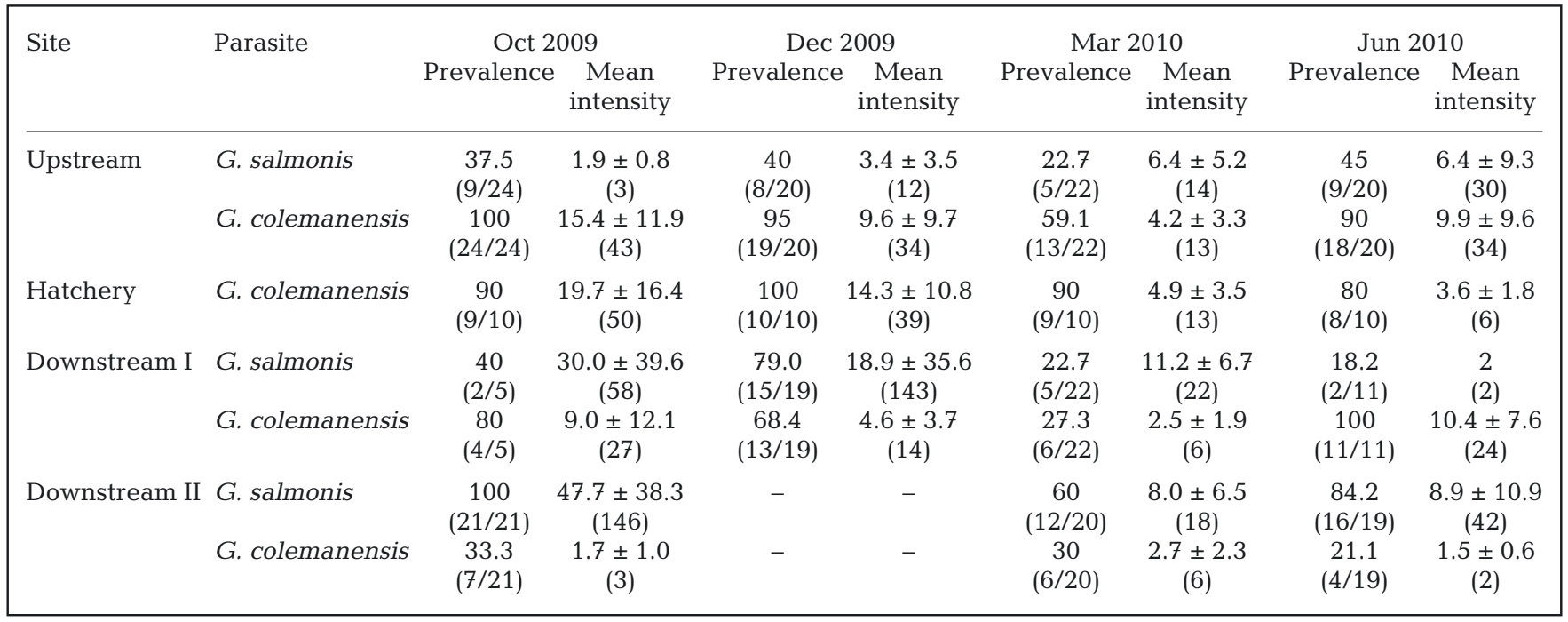


sis, $H=8.7$ to $14.3, \mathrm{p}<0.05)$ differed between sites, except for mean intensity in March 2010 (G. salmonis, $H=1.4, \mathrm{p}>0.5 ;$ G. colemanensis, $H=5.5, \mathrm{p}>0.1)$ and June for $G$. salmonis $(H=1.26, \mathrm{p}>0.5)$. Upstream, prevalence of $G$. colemanensis on brook trout was consistently higher than that of $G$. salmonis on all 4 sampling dates $\left(\chi^{2}=19.0 ; \mathrm{p}<0.001 ; \chi^{2}=11.4 ; \mathrm{p}<\right.$ $\left.0.001 ; \chi^{2}=4.6 ; \mathrm{p}<0.05 ; \chi^{2}=7.3 ; \mathrm{p}<0.01\right)$. In contrast, at Downstream I, G. colemanensis and G. salmonis had comparable prevalence in 3 of the 4 samples $\left(\chi^{2}=0.4 ; \mathrm{p}>0.05, \chi^{2}=0.1 ; \mathrm{p}>0.05 ; \chi^{2}=0.000 ; \mathrm{p}>\right.$ $\left.0.05 ; \chi^{2}=12.0 ; \mathrm{p}<0.001\right)$, while $1 \mathrm{~km}$ further downstream in the small tributary (Downstream II) the 2 parasites had similar prevalence values in March $2010\left(\chi^{2}=2.5 ; \mathrm{p}>0.05\right)$, but in October 2009 and June 2010 G. salmonis was higher $\left(\chi^{2}=18.1 ; \mathrm{p}<0.001 ; \chi^{2}\right.$ $=12.8 ; \mathrm{p}<0.001$ ) as was intensity (Table 3).

Prevalence and mean intensity on brook trout remained high at most locations during the seasonal samples (Table 3). Differences were found in both species at specific collection localities (Gyrodactylus salmonis, $\chi^{2}=2.2$ to $16.6 ;$ G. colemanensis, $\chi^{2}=0.78$ to 18.49) (G. salmonis, $H_{C}=3.8$ to $19.8 ;$ G. colemanensis, $H c=0.4$ to $14.8, \mathrm{p}=0.05$ ), but there was no discernable seasonal pattern (Table 3 ). What was apparent was a consistent dominance of the parasite species at the sampling localities (Table 3).

At the hatchery, prevalence of Gyrodactylus colemanensis on brook trout remained $80 \%$ or higher in the 4 seasonal samples $\left(\chi^{2}=2.2, \mathrm{p}>0.5\right.$; Table 3$)$, with a significant decrease in intensity during warmer temperatures of June $2010\left(H_{C}=16.8, \mathrm{p}<0.001\right.$; Table 3$)$. A total of 1 to 4 live G. colemanensis was found in 2801 water flowing from the hatchery at each sampling date (Table 4). Given the outflow rate from the hatchery (about $16.04 \times 10^{6} \mathrm{l} \mathrm{d}^{-1}$ ), we estimated that up to 230000 live parasites were exported per day from the hatchery (Table 4). Parasites were not found in 2801 of intake water sampled in June 2010.

Table 4. Gyrodactylus colemanensis. Number of live G. colemanensis present in subsamples of the outflow water leaving the hatchery, and total estimated daily export based on an average flow rate of $16.04 \times 10^{6} \mathrm{l} \mathrm{d}^{-1}$. In parentheses: number of dead parasites

\begin{tabular}{|lcccc|}
\hline Date & $\begin{array}{c}\text { Temperature } \\
\left({ }^{\circ} \mathrm{C}\right)\end{array}$ & $\begin{array}{c}\text { Flow rates } \\
\left(\mathrm{l} \mathrm{min}^{-1}\right)\end{array}$ & $\begin{array}{c}\text { Number } \\
\left(280 \mathrm{l}^{-1}\right)\end{array}$ & $\begin{array}{c}\text { Export } \\
\left(\mathrm{d}^{-1}\right)\end{array}$ \\
\hline Oct 2009 & 20 & 11364 & $4(2)$ & 229093 \\
Dec 2009 & 4 & 11364 & 1 & 57273 \\
Mar 2010 & 3.5 & 11364 & 2 & 114546 \\
Jun 2010 & 14 & 11364 & $3(4)$ & 171820 \\
Average & 10.4 & 11364 & 2.5 & 143183 \\
\hline
\end{tabular}

\section{DISCUSSION}

The parasite/host system studied is far from natural, as Gyrodactylus salmonis appears to be endemic on Salvelinus fontinalis, while Gyrodactylus colemanensis is likely an introduced species; the natural range of $G$. colemanensis is the west coast of North America (Gilmore et al. 2010). Similarly, S. fontinalis and Salmo salar are endemic to Nova Scotia, while Oncorhynchus mykiss and Salmo trutta are introductions, the former from freshwaters of Pacific North America and the latter from Europe (Scott \& Crossman 1973).

In the South River, the apparent invader, Gyrodactylus colemanensis, effectively disperses among all 4 salmonids (endemic and non-endemic), while the presumed endemic, G. salmonis, utilizes almost exclusively its natural Salvelinus fontinalis host. This restricted distribution must be ecologically driven because $G$. salmonis occurs in high numbers on Oncorhynchus mykiss and Salmo salar at hatcheries in the region (D. Cone unpubl. data). Different microhabitat preferences known for these salmonids (Gibson 1978, Fausch \& White 1981, Cunjak \& Green 1984) must somehow restrict dispersal of G. salmonis among host species in the river. In contrast, G. colemanensis overcomes any such restriction, making use of all of the different salmonids at comparably high levels. Such effective dispersal explains why $G$. colemanensis regularly shows up at the hatchery compared to only the rare appearance of G. salmonis on stocks (Cone \& Cusack 1988, D. Cone unpubl. data), with the parasite having access to the farm via intake water from the river.

Both parasites were on Salvelinus fontinalis at all sample localities, albeit at different prevalence values and intensities. One can assume such patchiness is related to differences in abiotic and biotic environments at the sampling localities (width, depth, flow rates, host-species composition and density, separate upstream headwaters) and how local transmission and population growth perform in relation to them. What surprised us was the stability of the resulting patchiness over the $9 \mathrm{mo}$, as $S$. fontinalis are active, with nocturnal forays up and down the river, with annual recruitment and seasonal migrations in and out of the South River estuary (Miles 1985). We assumed any local differences in parasite success would have been dismantled by such host vagility; but this was not the case. Admittedly, changes in prevalence and intensity could have been missed between samples, but, if they did fluctuate, they can be considered resilient local populations (Pimm 1991) 
because they returned to previous levels. Whatever the case, patchiness in local populations appeared to be stable and occurred within the remarkably small scale of $8 \mathrm{~km}$. Anttila et al. (2008) did show stable regional prevalence of Gyrodactylus salaris on Salmo salar in the River Tornionjoki, Finland, with high prevalence near the headwaters declining downstream to extinction on fish in the lower reaches, toward the Baltic Sea. The latter study, however, involved patchiness at a much larger scale, with localities covering $500 \mathrm{~km}$ of the river basin.

Our estimate of parasite export from the Fraser's Mills facility is the first attempt to do so at such a facility experiencing chronic gyrodactylosis. The daily export of 230000 live parasites surprised us, but, unfortunately, we can say little about infectivity of these parasites in the river. Species of Gyrodactylus have a direct life cycle and can be transferred directly among fish hosts that come into contact with each other, with drift and temporary use of a substrate also being possible alternate routes of transmission (Bakke et al.2007). The possibility exists then that parasites leaving the facility can reattach directly or indirectly onto wild hosts downstream. A detailed assessment of the impact of such an outflow of parasites on the gyrodactylid populations in the river would involve placing caged, parasite-free fish downstream of the farm and subsequent sampling. Such a study would serve a growing interest in determining whether farmed fish serve as potential foci of infection and vector of pathogens to wild fish (Valtonen \& Koskivaara 1994, Olivier 2002, Krkošek et al. 2007, You et al. 2006, 2008, Rosenberg 2008, Costello 2009, Murray 2009).

Acknowledgements. The authors thank the staff of the Fraser's Mills Fish Hatchery for assistance throughout the study and Reginald Madden and Amy Ryan for help with electro-fishing. The study was supported financially by the Nova Scotia Department of Fisheries and Aquaculture and, in part, by an NSERC Discovery Grant awarded to D.K.C. and the Fundamental Research Funds for the Central Universities in SNNU.

\section{LITERATURE CITED}

Anttila P, Romakkaniemi A, Kuusela J, Koski P (2008) Epidemiology of Gyrodactylus salaries (Monogenea) in the River Tornionjoki, a Baltic wild salmon river. J Fish Dis 31:373-382

Bailey R, Margolis L (1987) Comparison of parasite fauna of juvenile sockeye salmon (Oncorhynchus mykiss) from southern British Columbia. Can J Zool 65:420-431

Bakke TA, Cable J, Harris PD (2007) The biology of gyrodactylid monogeneans: the 'Russian-doll killers'. Adv Parasitol 64:161-376
Cone DK, Cusack R (1988) A study of Gyrodactylus colemanensis Mizelle and Kritsky, 1967 and Gyrodactylus salmonis (Yin and Sproston, 1948) (Monogenea) parasitizing captive salmonids in Nova Scotia. Can J Zool 66: 409-415

Cone DK, Beverly-Burton M, Wiles M, McDonald TE (1983) The taxonomy of Gyrodactylus (Monogenea) parasitizing certain salmonid fishes of North America, with a description of G. nerkae n. sp. Can J Zool 61:2587-2597

$>$ Costello MJ (2009) How sea lice from salmon farms may cause wild salmon declines in Europe and North America and be a threat to fishes elsewhere. Proc Biol Sci 276: 3385-3394

> Cunjak RJ, Green JM (1984) Species dominance by brook trout and rainbow trout in a simulated stream environment. Trans Am Fish Soc 113:737-743

Fausch KD, White RJ (1981) Competition between brook trout (Salvelinus fontinalis) and brown trout (Salmo trutta) for positions in a Michigan stream. Can J Fish Aquat Sci 38:1220-1227

Frimeth JP (1987a) A survey of the parasites of nonadromous and anadromous brook charr (Salvelinus fontinalis) in Tabusintac River, New Brunswick, Canada. Can J Zool 65:1354-1362

Frimeth JP (1987b) Potential use of certain parasites of brook charr (Salvelinus fontinalis) as biological indicators in Tabusintac River, New Brunswick, Canada. Can J Zool 65:1989-1995

Gibson RJ (1978) The behavior of juvenile Atlantic salmon, Salmo salar, and brook trout, Salvelinus fontinalis, in regard to temperature and to water velocity. Trans Am Fish Soc 107:703-712

Gilmore SL, Abbott CL, Cone DK (2010) Placement of Gyrodactylus salmonis (Yin \& Sproston) in the molecular phylogeny of studied species of the wageneri group. J Fish Dis 33:461-467

Hathaway RR, Herlevich JC (1973) Gyrodactylus stableri sp. n., with new host and locality records for species of Gyrodactylus. J Parasitol 59:801-802

Krkošek M, Gottesfeld A, Proctor B, Rolston D, Carr-Harris C, Lewis MA (2007) Effects of host migration, diversity and aquaculture on sea lice threats to Pacific salmon populations. Proc Biol Sci 274:3141-3149

MacMillan JL, Madden RJ (2007) Angler effort and harvest of sea-run brook trout from a specially regulated estuary, Nova Scotia, Canada. In: Carline RF, LoSapio C (eds) Sustaining wild trout in a changing world. Proceedings of wild trout IX symposium, October 9-12 2007. West Yellowstone, MT, p 186-193

Miles BL (1985). Some aspects of the biology of four salmonid species in the South River, Antigonish County, Nova Scotia, with special reference to the brook trout (Salvelinus fontinalis). MSc thesis, Department of Renewable Resources, MacDonald College, McGill University, Montreal

> Murray AG (2009) Using simple models to review the application and implications of different approaches used to simulate transmission of pathogens among aquatic animals. Prev Vet Med 88:167-177

Olivier G (2002) Disease interactions between wild and cultured fish-perspectives from the American Northeast (Atlantic Provinces). Bull Eur Assoc Fish Pathol 22:103109

Pimm SL (1991) The balance of nature. University of Chicago Press, Chicago, IL 
Rosenberg AA (2008) The price of lice. Nature 451:23-24

Scott WB, Crossman EJ (1973) Freshwater fishes of Canada. Fisheries Research Board of Canada, Ottawa

- Valtonen ET, Koskivaara M (1994) Relationships between the parasites of some wild and cultured fishes in two lakes and a fish farm in central Finland. Int J Parasitol 24: 109-118

von Gersdorff Jørgensen L, Heinecke P, Kania P, Buchmann K (2008) Occurrence of gyrodactylids on wild salmon Salmo salar L., in Danish waters. J Fish Dis 31:127-134

Editorial responsibility: David Marcogliese, Montreal, Quebec, Canada
You P, Yaun B, Young J, Easy R, Dong Z, Cone D (2006) Pathogenic infections of Gyrodactylus brachymystacis (Monogenea) on Oncorhynchus mykiss (Walbaum) at a fish farm in the Qinling Mountain region of China. J Fish Dis 29:313-316

You P, Wang Y, Qiang X, Sun X, Cone DK (2008) Seasonal dynamics of Gyrodactylus brachymystacis Ergens on captive Oncorhynchus mykiss (Walbaum) in the Qinling Mountain region of China. J Fish Dis 31: 941-945

Submitted: August 9, 2010; Accepted: May 30, 2011

Proofs received from author(s): August 25, 2011 